\title{
Assessment of total mercury content in tissues of Mullus argentinae in Rio de Janeiro, Brazil*
}

\section{Avaliação de mercúrio total em tecido comestível de Mullus argetinae coletados no Rio de Janeiro, Brasil}

\author{
Pedro Lopes Azevedo, ${ }^{* *}$ Julia Siqueira Simões, ${ }^{* *}$ Môsar Lemos, ${ }^{* *}$ Jane Silva Maia Casto, ${ }^{* *}$ Roberta de Oliveira Resende \\ Ribeiro, ${ }^{* *}$ Eliane Teixeira Mársico**
}

\begin{abstract}
This study has as objective to determine total mercury (Total Hg) levels by atomic absorption spectrophotometry in 134 individuals edible part of Mullus argentinae, in two different fishing areas and two seasons in Rio de Janeiro State. Also, proximate composition was performed. Total $\mathrm{Hg}$ results in wet weight basis ranged from 0.0867 to $0.7476 \mu \mathrm{g} . \mathrm{g}^{-1}$ in muscle; 0.0023 to $0,1034 \mu \mathrm{g} \cdot \mathrm{g}^{-1}$ in flippers; and 0.0177 to $0.1849 \mu \mathrm{g} \cdot \mathrm{g}^{-1}$ in skin. Mean evaluated moisture was $73.39 \%$; protein was $18.76 \%$; lipid concentration of $5.36 \%$; carbohydrates of $2.35 \%$; and ashes were $0.85 \%$. Results showed that Total $\mathrm{Hg}$ contents was lower than accepted limits established by regulatory organization. Higher averages were observed in muscle $\left(0.2441 \mu \mathrm{g} . \mathrm{g}^{-1}\right)$ when compared with skin $(0.2386$ $\left.\mu \mathrm{g} . \mathrm{g}^{-1}\right)$ and flippers $\left(0.0195 \mu \mathrm{g} . \mathrm{g}^{-1}\right)$. In general, samples collected on summer showed higher values of total $\mathrm{Hg}$ when comparing to winter. Regarding beach areas there was no significant difference $(p>0.05)$. We can conclude that this specie should be cautious consumed because of total $\mathrm{Hg}$ bioaccumulation characteristics, although neither levels were above limits established.
\end{abstract}

Keywords: bioaccumulation, demersal fish, direct mercury analyzer, spectrophotometry, trace elements.

\section{Resumo}

o objetivo deste estudo foi determinar o teor de mercúrio no tecido comestível de Mullus argentinae, conhecido como peixe trilha, espécie amplamente consumida no Rio de Janeiro, Brasil. Foi determinado o teor de mercúrio total ( $\mathrm{Hg}$ total) por espectrofotometria de absorção atômica em 134 amostras, coletados em duas áreas e estações climáticas diferentes. Além disso, foi avaliada a composição centesimal das amostras. Os resultados de $\mathrm{Hg}$ total em peso úmido variaram de 0,0867 a 0,7476 $\mu \mathrm{g} . \mathrm{g}-1$ no músculo;

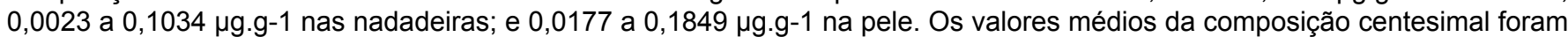
de $73,30 \%$ de umidade, $18,76 \%$ de proteína, $5,36 \%$ de lipídios, $2,35 \%$ de carboidratos e $0,85 \%$ de matéria mineral. Os resultados das 134 amostras analisadas demostraram que os teores de $\mathrm{Hg}$ Total apresentam concentração inferior aos limites aceitos pelos órgãos reguladores. As maiores médias foram observadas no músculo $(0,2441 \mu \mathrm{g} . \mathrm{g}-1)$ quando comparadas à pele $(0,2386 \mu \mathrm{g} . \mathrm{g}-1)$ e nadadeiras $(0,0195 \mu \mathrm{g} . \mathrm{g}-1)$. Em geral, as amostras coletadas no verão apresentaram maiores valores de $\mathrm{Hg}$ total em relação ao inverno. Em relação aos locais de coleta não houve diferença significativa $(p>0,05)$. Podemos concluir que esta espécie deve ser consumida com cautela devido às características de bioacumulação do $\mathrm{Hg}$ total, apesar das médias apresentadas estarem abaixo dos limites estabelecidos pela legislação.

Palavras-chave: analisador direto de mercúrio, bioacumulação, elementos traço, espectrometria, peixes demersais.

\section{Introduction}

Fish consumption is considered worldwide as a balanced and healthy diet once it provides high-quality protein, polyunsaturated such omega-3, other essential nutrients which are related as an important food matrix to ensure nutritional quality. Although, possible chemical contamination can lead to harmful effects on human healthy, including Alzheimer's disease, Parkinson's, Autism, depression, and anxiety. There are also reports since 2000s, about low dose mercury related to high blood pressure, an increase risk of heart attacks, and higher "bad" LDL cholesterol (ZAHIR et al. 2005; ZHANG et al. 2018).
Among inorganic contaminants in fish, the most worrying is mercury, one of the most toxic environmental pollutants, due to metillated form ( $\mathrm{MeHg}$ ) that could be incorporated by many animal species, including humans, throughout food chain by bioaccumulation process. It is well known that fish consumption is the major source for human mercury exposure. The path of methylmercury into the human body is explained through the formation of water-soluble methylmercury complexes in body tissues that are attached to thiol groups in protein, certain peptides, and amino acids (CLARKSON and MAGOS, 2006; FARINA and ASCHNER, 2019).

*Recebido em 24 de março de 2021 e aceito em 23 de novembro de 2021

**Universidade Federal Fluminense; Faculdade de Medicina Veterinária; Departamento de Tecnologia de Alimentos; Niterói; Rio de Janeiro, Brasil. 
As organic mercury's high or even low ingestion can lead to accumulation on muscles, bones, liver, kidneys and brain, agencies and governments worldwide developed regulations and recommendations to protect public health regarding toxic substances (DE AQUINO et al. 2017). In Brazil, it was established the maximum residue limits of $500 \mathrm{mg} \cdot \mathrm{kg}^{-1} \mathrm{Hg}$ for non-predatory fish and $1,000 \mathrm{mg}^{\mathrm{kg}}{ }^{-1} \mathrm{Hg}$ for predatory fish (COMMISSION 2006; BRAZIL 2013a).

The argentine goatfish (Mullus argentinae) is a great commercial important fish in Rio de Janeiro State, due to its low coast and flavor, being highly consumed on the coast. Inhabitant of subtropical marine water (LUQUE et al. 2002; DI AZEVEDO and IÑIGUEZ, 2018) the $M$. argentinae is a marine demersal benthonic and predatory fish living in depth range of $20-60 \mathrm{~m}$, occurring on south and southeast of Brazil (BONSIGNORE et al. 2018). As the flavor is like shrimp and is considered low cost, present high consumption, especially in the summer.

Therefore, the aim of this study was to determine total mercury concentration on $M$. argentinae in two beach areas and in different seasons in Southeastern, Brazil.

\section{Material and Methods}

A total of 134 individuals were caught from two fishing areas

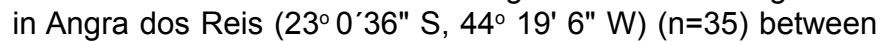
May and September of 2017 and Cabo Frio (22 $52^{\prime} 43^{\prime \prime} S 42^{\circ} 1^{\prime}$ $12^{\prime \prime}$ W) ( $\left.n=99\right)$ between March and October by local fishermen. Both areas were chosen due to the importance they represent in tourism in the southeast region and due to significant consumption of marine fish. The collections included months with different climatic variations, with the gold of evaluating the influence of seasonality on total $\mathrm{Hg}$ concentration, as well as evaluating possible differences between the capture areas. To evaluate the seasonality effects on total $\mathrm{Hg}$ concentration, samples were divided according the water temperature during catch. Between June and September, the average water temperature was $23,7^{\circ} \mathrm{C}$ whiles between October and May were $26,4^{\circ} \mathrm{C}$. Fishes were transported in isothermal containers with ice to Federal Fluminense University.

In laboratory conditions, samples of the muscles, fins and skin were comminuted and stored at $-20^{\circ} \mathrm{C}$ until the analyzes were performed.

The moisture was determinate by an infrared equipment (Mettler Toledo LJ16, São Paulo, Brazil); Crude protein was calculated by converting the nitrogen content, determined by micro Kjeldahl's method (AOAC 2016). Total lipid was determined according Soxhlet extraction method (AOAC 2016) and ash content using pre-dried samples obtained from moisture analysis using muffle oven at $550^{\circ} \mathrm{C}$. Carbohydrate content were calculated based on difference [Carbohydrate $=100 \%$ - $(\%$ moisture $+\%$ ash + $\%$ crude protein $+\%$ fat)]

Total $\mathrm{Hg}$ were determined using thermal decomposition amalgamation atomic absorption spectrometry method (TDAAAS), with a direct mercury analyzer (DMA - 80 Milestone ${ }^{\circledR}$, Sorisole (BG), Italy) using US-EPA 7473:2007 method. Quartz samples boats (Milestone, DMA 8347) were used in an automatic sampler. The pyrolysis process (sample heated) was controlled by an internal thermocouple (ATC). Then, $\mathrm{Hg}$ is trapped in a gold amalgamator (Milestone, DMA 8134). To ensure $\mathrm{Hg}$ reduction in this stage a catalyst system is employed (Milestone, DMA 8333). After trapped mercury, the gold amalgamator is heated and a system consisting of a low-pressure mercury vapor lamp, which emits light at 253,65 $\mathrm{nm}$ wave length and a silicon UV diode as a detector performs the detection of elemental mercury. Oxygen (White Martins, São Paulo, Brazil) was used as reagent and carrier gas for $\mathrm{Hg}$ vapours. The optimized conditions for drying and decomposition (pyrolysis) using $60 \mathrm{mg}$ of sample were 200 ${ }^{\circ} \mathrm{C}$ for $60 \mathrm{~s}$ and $600^{\circ} \mathrm{C}$ for $180 \mathrm{~s}$, respectively. The instrument was calibrated each day using standard reference materials (SRM). Blanks (an empty boat) and standard reference material were analysed at the beginning of every batch of 10 samples to assess accuracy to quantify total $\mathrm{Hg}$ a calibration curve was elaborate $\left(R^{2}=0,993\right)$.

All material used was decontaminated washing with a common detergent rinsing twice with Milli $Q$ quality water and soaking into a clean diluted $\mathrm{HNO}_{3} 20 \%(\mathrm{v} / \mathrm{v})$ bath for $48 \mathrm{~h}$, rising with ultra-pure water (Milli-Q). Finally, all material was dried in clean environment. All the reagents were of analytical grade.

Accuracy of the results was checked by using certified reference material from National Institute for Science and Technology (NIST 1577b-bovine liver) and International Atomic Energy Agency (IAEA 336-lichen) in triplicate analyses. Quartz samples boats were washed, rinsed, dried, and heated at $650^{\circ} \mathrm{C}$ for $3 \mathrm{~min}$ in DMA-80 analyzer. Total mercury quantified in the reference materials were within 87 and $86 \%$ of the mean certified values. Calibration curves were prepared by successive dilutions of a certified standard solution at $1000 \mathrm{mg} \mathrm{L}^{-1}$ of $\mathrm{Hg}$ in $0.5 \%(\mathrm{v} / \mathrm{v}) \mathrm{HNO}_{3}$.

Data were analyzed using Graph Pad Prism 5.0 software. T-test was used for means and standard deviations. One-way ANOVA was used to estimate differences between fish species. The significance level was $p<0.05$.

\section{Results and Discussion}

\section{Proximate composition}

The proximate composition in most fish, according to F.A.O.I W.H.O. (2011), is primarily water, proteins, and lipids making up about $98 \%$ of the total mass, and the other minor constituents include carbohydrates, vitamins, and minerals and can varies due to factors as seasonal condition, diet, sex and habitat (Rani et al. 2016; Wu et al. 2019; Hossain et al. 2019), geographical locations, stages of maturity, and sizes (W.H.O./F.A.O. 2010; ROMOTOWSKA et al. 2016; FERNANDES et al. 2018; LINHARTOVÁ et al. 2018). According to Stancheva et al. (2013) edible fish tissue contains $60-84 \%$ water, $15-24 \%$ protein and $0.1-22 \%$ lipids. The proportions of the constituents are speciesspecific and the main variations in proximate composition between species occurs in moisture and lipids content. Formers reports, suche as Jacquot (1961) and Pal et al. (2018) already described that environmental factors such as living conditions and eating habits, can affect the chemical composition of fish. Rulev and Makarova (1959) and Abraha et al. (2018) already observed a difference in the levels of moisture, protein and lipids according to the season, as well as Ludorf (1963) and Bandarra et al. (2018) who described the place of capture as variable for fish composition.

In this study, no differences ( $p>0.05$ ) were observed between areas and seasons for moisture, protein, lipid and ash (wet basis). Moisture was $73.35 \%$ on average, protein ranged between 
$14.58 \%$ to $23.18 \%$, lipid and ash were $5.49 \%$ and $0.88 \%$ on average respectively.

Table 1: Proximate composition (\%) in Mullus argentinae captured in beach areas, Angra dos Reis and Cabo Frio, Rio de Janeiro, Brazil.

\begin{tabular}{cccccc}
\hline & Moisture & Protein & Lipid & Carbohidrates & Ashes \\
\hline Angra dos & $73.39 \pm$ & $18.76 \pm$ & $5.36 \pm$ & $2,35 \pm 1,75^{\mathrm{a}}$ & $0.85 \pm$ \\
Reis & $3.55^{\mathrm{a}}$ & $2.31^{\mathrm{a}}$ & $1.57^{\mathrm{a}}$ & & $0.10^{\mathrm{a}}$ \\
& $73.31 \pm$ & $17.84 \pm$ & $5.67 \pm$ & & \\
Cabo Frio & $2.82^{\mathrm{a}}$ & $1.64^{\mathrm{a}}$ & $2.14^{\mathrm{a}}$ & $2,26 \pm 1,8^{\mathrm{a}}$ & $0.93 \pm$ \\
& & & & $0.10^{\mathrm{a}}$
\end{tabular}

$\mathrm{a}, \mathrm{b}$ Different letters in the same column indicate significant difference $(p<0,05)$

Generally, most type of marine organisms are characterized by lipid levels lower than 3\%. The results from the present study demonstrated that this species was also characterized by a medium lipid content (4-8 g.100 g $\mathrm{g}^{-1}$ w.w.). Tropical water fish have lower lipid content when compared to cold water (ARMSTRONG et al. 1991; DE SOUZA et al. 2020). This variation occurs not only due to the water temperature, but also due to the need for food of different species during times of growth and reproduction, and also due to the availability of food, changing the use of the lipid stock by the fish (MARSHALL et al. 1999; MUELLER et al. 2017; CHANG et al. 2018).

The average moisture content for fish according to Hart and Fisher (1997) varies from 64 to $90 \%$ and may vary according to several factors, including the time of collection. As for the carbohydrate content, the concentrations show little variation between species and the results obtained in this study are similar to those found by Siddique et al. (2012) and Suvitha (2015).

Demersal species generally have lower lipid and energy values as commented by Ball et al. (2007) and Kaewmanee et al. (2015). This fact is related to demersal diet and feeding habits, which also interferes in fatty acid proportions as reported by Würzberg et al. (2011). Vollenweider et al. (2010) observed that species inhabiting deep waters have lower lipid content because the environment where they live is less influenced by climate change, requiring less energy expenditure to carry out their biological activities. As the food base of demersal species is inhabitant of deep waters, consequently their lipid content is also low. The effects of marine fish lipids on coronary heart disease, atherosclerosis, thrombosis, and blood pressure have been studied by various authors (PRATO and BIANDOLINO 2012; GIL and GIL 2015; CHANG et al. 2017; JOHNSEN et al. 2018). One of the reasons is that marine fish are the most excellent sources of n-3 PUFA (polyunsaturated fatty acids) for human health (CONWAY et al. 2018; ZACEK et al. 2018).

Protein content of fish is considered low if it is below $15 \%$. In this study, edible tissue showed good protein levels $(14,58-23,18 \%)$. Njinkoue et al. (2016) and Durmus et al. (2017) obtained similar protein levels in marine fish as this study. Fish protein intake bring benefits for human health, since it provides essential amino acids, such as lysine and methionine (Béné et al. 2015), and antioxidant peptides (Sila and Bougatef 2016). Besides, according FAO (2020), fish represented $17 \%$ of the global population's intake of animal protein and 7\% of all protein consumed in 2017.

Despite nutritional value of fish, it is important to point that environmental pollution can interfere with this concept, causing damage to the quality of fish as food. We must consider that organic mercury is lipophilic and can also interfere in lipid quality.

\section{Mercury determination}

Few studies have considered mercury content and proximate composition in Mullus argentinae captured in the subject areas of this study.

According to F.A.O./W.H.O. (2018) Hg is one of the most toxic elements among the studied heavy metals and exposure to high level of this element could permanently damage the brain, kidneys and developing fetus. In the present study, selective portions were chosen because their contamination degree is related to the degree of contamination of the muscle as describes by Cervenka et al. (2011). As in the species evalueted in this study the fins are also consumed, finding out the degree of contamination of them is essential to calculate the risk of intoxication.

The higher detected averages of $\mathrm{Hg}$ in samples from Angra dos Reis $(n=35)$ and Cabo Frio $(n=99)$ were in muscle $(0,1707$ and 0,2269 mg.kg-1 w.w), whereas flippers contain the lowest averages $(0,0126$ and $0,0212 \mathrm{mg} . \mathrm{kg}-1 \mathrm{w} . \mathrm{w})$ as shown in Table 2. Muscle has a high potential for mercury accumulation due to the chemical affinity of the contaminant with the thiol group of amino acids, while the mercury concentrations in the skin are due to the adsorption process directly from the environment in which they are found (Polak-Juszczak, 2018).

Table 2: Total Hg $\left(\mu \mathrm{g} \cdot \mathrm{g}^{-1}\right)$ in muscle, flippers and skin of Mullus argentinae captured in different water temperature $\left(26,4^{\circ} \mathrm{C}\right.$ and $\left.23,7^{\circ} \mathrm{C}\right)$ in Cabo Frio and Angra dos reis, Rio de Janeiro, Brazil.

\begin{tabular}{ccc}
\hline & $26,4^{\circ} \mathrm{C}$ & $23,7^{\circ} \mathrm{C}$ \\
\hline Muscle & $0.1707 \pm 0.0021^{\mathrm{b}}$ & $0.2269 \pm 0.0145^{\mathrm{a}}$ \\
Flippers & $0.0126 \pm 0.0012^{\mathrm{a}}$ & $0.0212 \pm 0.0028^{\mathrm{a}}$ \\
Skin & $0.0813 \pm 0.0016^{\mathrm{b}}$ & $0.1399 \pm 0.0048^{\mathrm{a}}$ \\
\hline
\end{tabular}

$a, b$ Different letters in the same row indicate significant difference $(p<0.05)$.

Compared to our results Naccari et al. (2015), Jeevanaraj et al. (2016) and Sánchez-Muros et al. (2018) had similar results in demersal fish. Demersal species generally accumulate higher concentrations of heavy metals than pelagic fish (JIANG et al. 2018). The same occurs when compared benthic and pelagic fish species (HOSSEINI et al. 2013; MONIKH et al. 2013; ARCAGNI et al. 2018), mainly related to diet and feeding habits. In addition to diet and eating habits, total $\mathrm{Hg}$ in edible tissue may vary due to biological and environmental factors such as size, weight, lipid content, climatic variations, geographical conditions and pollution (WOLFF et al. 2016; AZAD et al. 2019; SILVA et al. 2019).

Temporal variations of total mercury concentration were detected in muscle and skin. Higher averages were observed in lower water temperature. Eutrophication may be the reason of this difference. This process influences nutrients availability in the aquatic ecosystem, which can lead to different levels of mercury contamination (CRESSON et al. 2015; DODDS and SMITH 2017). Poste et al. (2015) demonstrate in their study that a high phytoplankton biomass and growth rates, which occurs during eutrophication process, may reduce the potential for high total mercury in fish. Active phytopalnkton biomass is higher in larger 
temperatures in tropical waters (COTOVICZ JR. et al. 2017) which elucidates the lower concentrations of total mercury in hot weather in this study.

Angra dos Reis and Cabo Frio attract economic activities due to their scenic tourism. Although these activities generate income and employment, they also bring destruction to the natural environment, including water pollution of oceans and rivers (Silva et al. 2011; Guerra et al. 2013). Mercury levels in fish sampled from two sampling locations showed significant differences (Table 3). Higher mercury averages in muscle and skin were found in fish sampled from Angra dos Reis $\left(0.3017 \mu \mathrm{g} . \mathrm{g}^{-1}\right.$ for muscle, $0.0193 \mu \mathrm{g} \cdot \mathrm{g}^{-1}$ for flippers and $0.3105 \mu \mathrm{g} . \mathrm{g}^{-1}$ for skin). The difference in concentrations can be explained by the intense idustrial activity in the region, which increases the concentration of waste dumped in the environment (Brazil 2017b), increasing the levels of environmental pollution and methylating bacteria, making it possible to increase the levels of methyl mercury bioavailable in the aquatic environment.

Table 3: Total Hg ( $\left.\mu \mathrm{g} . \mathrm{g}^{-1}\right)$ in muscle, flippers and skin of Mullus argentinae captured in beach areas Angra dos Reis and Cabo Frio, Rio de Janeiro, Brazil.

\begin{tabular}{ccll}
\hline & Muscle & Flippers & Skin \\
\hline Angra dos & $0.3017 \pm$ & $0.1289 \pm$ & $0.2186 \pm$ \\
Reis & $0.1287^{\mathrm{a}}$ & $0.1057^{\mathrm{a}}$ & $0.1497^{\mathrm{a}}$ \\
& $0.1886 \pm$ & $0.0946 \pm$ & $0.0976 \pm$ \\
Cabo Frio & $0.0847^{\mathrm{b}}$ & $0.0339^{\mathrm{a}}$ & $0.0637^{\mathrm{b}}$ \\
\hline
\end{tabular}

$\mathrm{a}, \mathrm{b}$ Different letters in the same column indicate significant difference $(p<0,05)$.

Another factor that may have influenced the total $\mathrm{Hg}$ concentrations in the two regions is the resurgence phenomenon. This phenomenon is characterized by the alteration of marine currents and, consequently, greater circulation of water. During the resurgence cold water currents rich in nutrients rise from the deepest areas of the oceans and at the same time movements of surface hot water currents can occur that go to the depths (PEREIRA et al. 2018). The encounter between the two currents leads to a high dispersion of nutrients and methylating bacteria present in the water, including contaminants, such as methyl mercury (LOHMANN and BELKIN 2014; COALE et al. 2018).

All concentrations obtained in this study were below the maximum limits established by Brazilian legislation for sea fish, which is $1.0 \mathrm{mg} / \mathrm{kg}$ w.w. to carnivorous and $0.5 \mathrm{mg} / \mathrm{kg} \mathrm{w} . \mathrm{w}$ for the others species (BRAZIL, 2013a). Although the concentrations have

\section{References}

ABRAHA, B.; ADMASSU, H.; MAHMUD, A.; TSIGHE, N.; SHUI, X. W.; FANG, Y. J. Effect of processing methods on nutritional and physico-chemical composition of fish: a review. MOJ Food Processing \& Techonology, v.6, n. 4, p. 376-382, 2018.

AOAC. Official method of analysis of AOAC International. 20th ed. Virginia: Association of Official and Analythical Chemist International, 2016.

ALPERS, C.N.; FLECK, J.A.; MARVIN-DIPASQUALE, M.; STRICKER, C.A.; STEPHENSON, M.; TAYLOR, H.E. Mercury cycling in agricultural and managed wetlands, Yolo Bypass, California: Spatial and seasonal variations in water quality. Science of The Total Environment, v. 484, p. 276-287, 2014. not exceeded the maximum residue limits, studies evaluating the risk according to the daily or weekly consumption of this species by the population are necessary. This must be taken into account since the frequency of fish consumption varies according to the geographical region of the population. Riverside populations in the Amazon region reach a consumption per capita of approximately $148 \mathrm{~kg} / \mathrm{hab} /$ year (OLIVEIRA 2010), while the average consumption in Latin America in 2017 was $10,5 \mathrm{~kg} / \mathrm{hab} /$ year (F.A.O. 2020). In addition, some samples from this study showed contamination levels above $0.7 \mathrm{mg} / \mathrm{kg} \mathrm{w} . \mathrm{w}$, close to the maximum limit stipulated by legislation.

This study has a great importance whereby mercury was determined in different geographical areas over different periods. Several interesting findings can be reached from this study: The data indicated that mercury levels differed significantly among the areas, and thropic level correlations with mercury, which benthonic and demersal species usually shows higher mercury levels due to their diet and feeding habits as demonstrate by Liu et al. (2014), Bonsignore et al. (2015) and Annual et al (2018). Another important factor that affects mercury contamination in fish is bioaccumulation process based on its bioavailability, uptake, and toxicokinetics according to Xu et al. (2018). Other additional recorded factors were physiological differences between different fish species, migration from unpolluted areas to relatively more polluted areas. Benthic species are more exposed to higher concentrations of methylmercury in the sediment $(\mathrm{CHOI}$ et al. 2019) and of their specific prey (JOHNSON et al. 2015). This reflected the area variations that may be due to the highest values of mercury in the marine environment where high methylation rates occurred (ALPERS et al. 2014; EAGLES-SMI et al. 2016).

\section{Conclusion}

We can conclude that average concentration of total $\mathrm{Hg}$ has not exceed according to regulamentary limits. Mercury concentration were significantly affected by season and capture locations (Angra dos Reis, $n=35$ and Cabo Frio, $n=99$ ). Due to the high values observed in the skin, it can be inferred that the mercury adsorption mechanism, especially in the Angra dos Reis region, is the main route, suggesting that water may be a possible contamination vehicle. Also, it should be considered further studies including Provisional Tolerable Weekly Intake (PTWI) for this specie, especially when increase consumption, during summer.

Acknowledgements: The author and this research were financed by Conselho Nacional de Desenvolvimento Científico e Tecnológico (CNPq; Grant number 311974/2019-8).

ANUAL, Z.F.; MAHER, W.; KRIKOWA, F.; HAKIM, L.; AHMAD, N.I.; FOSTER, S. Mercury and risk assessment from consumption of crustaceans, cephalopods and fish from West Peninsular Malaysia. Microchemical Journal, v. 140, p. 214-221, 2018.

AQUINO, L.F.M.C.D.; RIBEIRO, R.D.O.R.; SIMOES, J S.; MANO, S.B.; MÁRSICO, E.T.; CONTE JUNIOR, C.A. Mercury content in whey protein and potential risk for human health. Journal of Food Composition and Analysis, v. 59, p. 141-144, 2017.

ARCAGNI, M.; JUNCOS, R.; RIZZO, A.; PAVLIN, M.; FAJON, V.; ARRIBÉRE, M.A.; HORVAT, M.; RIBEIRO GUEVARA, S. Species- and habitat-specific bioaccumulation of total mercury and methylmercury in the food web of a deep oligotrophic lake. Science of The Total Environment, v. 612, p. 1311-1319, 2018. 
ARMSTRONG, S.G.; LEACH, D.N.; WYLLIE, S.G. Nutritional evaluation of lipids in fish from temperate Australian waters. Journal of Food Science, v. 56, n. 4, p. 1111-1112, 1991.

AZAD, A.M.; FRANTZEN, S.; BANK, M.S.; NILSEN, B.M.; DUINKER, A.; MADSEN, L.; MAAGE, A. Effects of geography and species variation on selenium and mercury molar ratios in Northeast Atlantic marine fish communities. Science of The Total Environment, v. 652, p. 1482-1496, 2019.

BALL, A.O.; BEAL, M.G.; CHAPMAN, R.W.; SEDBERRY, G.R. Population structure of red porgy, Pagrus pagrus, in the Atlantic Ocean. Marine Biology, v. 150, n. 6, p. 1321-1332, 2007.

BANDARRA, N. M.; MARÇALO, A.; CORDEIRO, A. R.; POUSÃOFERREIRA, P. Sardine (Sardina pilchardus) lipid composition: Does it change after one year in captivity? Food Chemistry, v. 244, p. 408-413, 2018.

BÉNÉ, C.; BARANGE, M.; SUBASINGHE, R.; PINSTRUPANDERSEN, P.; MERINO, G.; HEMRE, G.I.; WILLIAMS, M. Feeding 9 billion by 2050 - Putting fish back on the menu. Food Security, v. 7, n. 2, p. 261-274, 2015.

BONSIGNORE, M.; TAMBURRINO, S.; OLIVERI, E.; MARCHETTI, A.; DURANTE, C.; BERNI, A.; QUINCI, E.; SPROVIERI, M. Tracing mercury pathways in Augusta Bay (southern Italy) by total concentration and isotope determination. Environmental Pollution, v. 205, p. 178-185, 2015.

BONSIGNORE, M.; SALVAGIO MANTA, D.; MIRTO, S.; QUINCI, E.M.; APE, F.; MONTALTO, V.; GRISTINA, M.; TRAINA, A.; SPROVIERI, M. Bioaccumulation of heavy metals in fish, crustaceans, molluscs and echinoderms from the Tuscany coast. Ecotoxicology and Environmental Safety, v. 162, p. 554-562, 2018.

BRAZIL. Resolução - RDC N 42, 29 de Agosto de 2013. Regulamento técnico MERCOSUL sobre limites máximos de contaminantes inorgânicos em alimentos, 2013a Retrieved from http://www.gov.br/anvisa/pt-br

BRAZIL. 2013b. Elaboração de uma avaliação ambiental estratégica nos polos turísticos do Estado do Rio de Janeiro: Programa nacional do desenvolvimento do turismo (PRODETUR - RJ), 2013b. Retrieved from http://www.antigo.turismo.gov.br

ČERVENKA, R.; BEDNAŘíK, A.; KOMÁREK, J.; ONDRAČKOVÁ, M.; JURAJDA, P.; VÍTEK, T.; SPURNÝ, P.J.O.C. The relationship between the mercury concentration in fish muscles and scales/ fins and its significance. Central European Journal of Chemistry, v. 9 , n. 6 , p. 1109-1116, 2011.

CHANG, W.I.; AZRINA, A.; SABARIAH, M.N.; IRMI ZARINA, I.; LOH, S.P. Effects of Consuming Yellowstripe Scad versus Salmon on Lipid Profile, Fasting Glucose, Body Weight Status and Blood Pressure among Healthy Overweight Malaysian Adults. Malaysian Journal of Nutrition, v. 23, n. 3, p. 434-452, 2017.

CHANG, J.; NIU, H.; JIA, Y.; LI, S.; XU, G. Effects of dietary lipid levels on growth, feed utilization, digestive tract enzyme activity and lipid deposition of juvenile Manchurian trout, Brachymystax lenok (Pallas). Aquaculture Nutrition, v. 24, n. 2, p. 694-701, 2018.

CHOI, H.; JEONG, E.; NGUYEN, V.H.; HANH, D.V.B.; DAN, N.P.; SHIN, K.H.; HAN, S. Characteristics of sediment affecting monomethylmercury accumulation in benthic fish of the Mekong Delta. Environmental Toxicology Chemistry, v. 38, n. 3, p. 503510, 2019.

CLARKSON, T.W.; MAGOS, L. The Toxicology of Mercury and Its Chemical Compounds. Critical Reviews in Toxicology, v. 36, n. 8, p. 609-662, 2006.
COALE, K.H.; HEIM, W.A.; NEGREY, J.; WEISS-PENZIAS, P.; FERNANDEZ, D.; OLSON, A.; CHISWELL, H.; BYINGTON, A.; BONNEMA, A.; MARTENUK, S.; NEWMAN, A.; BEEBE, C.; TILL, $C$. The distribution and speciation of mercury in the California current: Implications for mercury transport via fog to land. Deep Sea Research Part II: Topical Studies in Oceanography, v. 151, p. 77-88, 2018.

COMMISSION. Commission regulation (EC) No 1881 of 19 december 2006 setting maximum levels of certain contaminants in foodstuffs, 2006. Retrieved from https://eur-lex.europa.eu/legalcontent/EN/TXT/PDF/?uri=CELEX:32006R1881\&from=EN

CONWAY, M.; MULHERN, M.; MCSORLEY, E.; VAN WIJNGAARDEN, E.; STRAIN, J.; MYERS, G.; DAVIDSON, P.; SHAMLAYE, C.; YEATES, A. Dietary determinants of polyunsaturated fatty acid (PUFA) status in a high fish-eating cohort during pregnancy. Nutrients, v. 10, n. 7, p. 927, 2018.

COTOVICZ, L.C.; KNOPPERS, B.A.; BRANDINI, N.; POIRIER, D.; SANTOS, S.J.C.; CORDEIRO, R.C.; ABRIL, G. Predominance of phytoplankton-derived dissolved and particulate organic carbon in a highly eutrophic tropical coastal embayment (Guanabara Bay, Rio de Janeiro, Brazil). Biogeochemistry Letters, v. 137, n. 1-2, p. 1-14, 2018.

CRESSON, P.; BOUCHOUCHA, M.; MIRALLES, F.; ELLEBOODE, R.; MAHÉ, K.; MARUSCZAK, N.; THEBAULT, H.; COSSA, D. Are red mullet efficient as bio-indicators of mercury contamination? A case study from the French Mediterranean. Marine Pollution Bulletin, v. 91, n. 1, p. 191-199, 2015.

DE SOUZA, A. F. L.; PETENUCI, M. E.; CAMPARIM, R.; VISENTAINER, J. V.; DA SILVA, A. J. I. Effect of seasonal variations on fatty acid composition and nutritional profiles of siluriformes fish species from the amazon basin. Food Research International, v. 132, p. 109051, 2020.

DI AZEVEDO, M.I.N.; IÑIGUEZ, A.M. Nematode parasites of commercially important fish from the southeast coast of Brazil: Morphological and genetic insight. International Journal of Food Microbiology, v. 267, p. 29-41, 2018.

DODDS, W.K.; SMITH, V.H. Nitrogen, phosphorus, and eutrophication in streams. Inland Waters, v. 6, n. 2, p. 155-164, 2016.

DURMUŞ, M.; KOSKER, A.R.; OZOGUL, Y.; AYDIN, M.; UÇAR, Y.; AYAS, D.; OZOGUL, F. The effects of sex and season on the metal levels and proximate composition of red mullet (Mullus barbatus Linnaeus 1758) caught from the Middle Black Sea. Human and Ecological Risk Assessment: An International Journal, v. 24, n. 3, p. 731-742, 2018.

EAGLES-SMITH, C.A.; WIENER, J.G.; ECKLEY, C.S.; WILLACKER, J.J.; EVERS, D.C.; MARVIN-DIPASQUALE, M.; OBRIST, D.; FLECK, J.A.; AIKEN, G.R.; LEPAK, J.M.; JACKSON, A.K.; WEBSTER, J.P.; STEWART, A.R.; DAVIS, J.A.; ALPERS, C.N.; ACKERMAN, J.T. Mercury in western North America: A synthesis of environmental contamination, fluxes, bioaccumulation, and risk to fish and wildlife. Science of The Total Environment, v. 568, p. 1213-1226, 2016.

F.A.O.M.H.O. Report of the joint F.A.O./W.H.O. expert consulation on the risks and benefits of fish consumption. Rome (Italy): Food and Agriculture Organization of the United Nations, 2010b.

F.A.O./W.H.O. Report of the joint F.A.O./W.H.O. expert committee on food additivies. India: World Health Organization, 2011. 
F.A.O./W.H.O. Codex alimentarius: General standard for contaminants and toxins in food and feed. Food and Agriculture Organization of the United Nations/World health organization, 2018.

F.A.O. The state of world fisheries and aquaculture: Sustainability in action. Rome (Italy): Food and agriculture organization of the united nations, 2020.

FARINA, M.; ASCHNER, M. Glutathione antioxidant system and methylmercury-induced neurotoxicity: an intriguing interplay. $B B A$ - General Subjects, v. 1863, n. 12, p. 129285, 2019.

FERNANDES, I.; NOGUEIRA, N.; FARIA, G.; FERNANDES, T.; FARIA, M.; CORDEIRO, N. Lipid and Fatty Acid Composition of Wild Almaco Jack Seriola rivoliana at Two Maturation Stages. Turkish Journal of Fisheries Aquatic Sciences, v. 18, n. 8, p. 959-967, 2018.

GIL, A.; GIL, F. Fish, a Mediterranean source of n-3 PUFA: benefits do not justify limiting consumption. British Journal of Nutrition, v. 113, n. S2, p. S58-S67, 2015.

GUERRA, A.J.T.; BEZERRA, J.F.R.; JORGE, M.D.C.O.; FULLEN, M.A. The geomorphology of Angra dos Reis and Paraty municipalities, southern Rio de Janeiro state. Revista Geonorte, v. 4, n. 13, p. 1-21, 2013.

HART, F.L, FISCHER, H.J. Carne y productos cárnicos. Spain: Acribia, 1997, 249 p.

HOSSAIN, M.A.; AL-ABDUL-ELAH, K.; YASEEN, S.B. Seasonal variations in proximate and fatty acid composition of sobaity sea bream (Sparidentex hasta) in Kuwait waters. Journal of the Marine Biological Association of the United Kingdom, v. 99, n. 4, p. 991-998, 2019.

HOSSEINI, M.; NABAVI, S.M.B.; PARSA, Y. Bioaccumulation of Trace Mercury in Trophic Levels of Benthic, Benthopelagic, Pelagic Fish Species, and Sea Birds from Arvand River, Iran. Biological Trace Element Research, v. 156, n. 1, p. 175-180, 2013.

JACQUOT, R. 1961. Organic constituents of fish and other aquatic animal foods. In: JACQUOT, R. Fish as food. Netherlands: Elsevier, 1961, p. 145-209.

JEEVANARAJ, P.; HASHIM, Z.; ELIAS, S.M.; ARIS, A.Z. Mercury accumulation in marine fish most favoured by Malaysian women, the predictors and the potential health risk. Environmental Science and Pollution Research, v. 23, n. 23, p. 23714-23729, 2016.

JIANG, Z.; XU, N.; LIU, B.; ZHOU, L.; WANG, J.; WANG, C.; DAI, B.; XIONG, W. Metal concentrations and risk assessment in water, sediment and economic fish species with various habitat preferences and trophic guilds from Lake Caizi, Southeast China. Ecotoxicology and Environmental Safety, v. 157, p. 1-8, 2018.

JOHNSEN, S.H.; JACOBSEN, B.K.; BRÆKKAN, S.K.; HANSEN, J.B.; MATHIESEN, E.B. Fish consumption, fish oil supplements and risk of atherosclerosis in the Troms $\varnothing$ study. Nutrition Journal, v. 17, n. 1, p. 56, 2018.

JOHNSON, B.M.; LEPAK, J.M.; WOLFF, B.A. Effects of prey assemblage on mercury bioaccumulation in a piscivorous sport fish. Science of The Total Environment, v. 506-507, p. 330-337, 2015.

KAEWMANEE, T.; KARRILA, T.T.; BENJAKUL, S. Effects of fish species on the characteristics of fish cracker. International Food Research Journal, v. 22, n. 5, p. 2078-2087, 2015.

LINHARTOVÁ, Z.; KREJSA, J.; ZAJÍC, T.; MÁSÍLKO, J.; SAMPELS, S.; MRÁZ, J. Proximate and fatty acid composition of 13 important freshwater fish species in central Europe. Aquaculture International, v. 26, n. 2, p. 695-711, 2018.
LIU, J.; XU, X.; YU, S.; CHENG, H.; HONG, Y.; FENG, X. Mercury pollution in fish from South China Sea: Levels, species-specific accumulation, and possible sources. Environmental Research, v. 131, p. 160-164, 2014.

LOHMANN, R.; BELKIN, I.M. Organic pollutants and ocean fronts across the Atlantic Ocean: A review. Progress in Oceanography, v. 128, p. 172-184, 2014.

LUQUE, J.; PORROZZI, F.; ALVES, D. Community ecology of the metazoan parasites of Argentine goatfish, Mullus argentinae (Osteichthyes: Mullidae), from the coastal zone of the state of Rio de Janeiro, Brazil. Revista Brasileira de Parasitologia Veterinária, v. 11, n. 1, p. 33-38, 2002.

MARSHALL, C.T.; YARAGINA, N.A.; LAMBERT, Y.; KJESBU, O.S. Total lipid energy as a proxy for total egg production by fish stocks. Nature, v. 402 , n. 6759 , p. $288,1999$.

MONIKH, F.A.; SAFAHIEH, A.; SAVARI, A.; DORAGHI, A. Heavy metal concentration in sediment, benthic, benthopelagic, and pelagic fish species from Musa Estuary (Persian Gulf). Environmental Monitoring and Assessment, v. 185, n. 1, p. 215-222, 2013.

MUELLER, C.A.; DOYLE, L.; EME, J.; MANZON, R.G.; SOMERS, C.M.; BOREHAM, D.R.; WILSON, J.Y. Lipid content and fatty acid profile during lake whitefish embryonic development at different incubation temperatures. Comparative Biochemistry and Physiology Part A: Molecular \& Integrative Physiology, v. 203, p. 201-209, 2017.

NACCARI, C.; CICERO, N.; FERRANTELLI, V.; GIANGROSSO, G.; VELLA, A.; MACALUSO, A.; NACCARI, F.; DUGO, G. Toxic Metals in Pelagic, Benthic and Demersal Fish Species from Mediterranean FAO Zone 37. Bulletin of Environmental Contamination and Toxicology, v. 95, n. 5, p. 567-573, 2015.

NJINKOUE, J.M.; GOUADO, I.; TCHOUMBOUGNANG, F.; NGUEGUIM, J.H.Y.; NDINTEH, D.T.; FOMOGNE-FODJO, C.Y.; SCHWEIGERT, F.J. Proximate composition, mineral content and fatty acid profile of two marine fishes from Cameroonian coast: Pseudotolithus typus (Bleeker, 1863) and Pseudotolithus elongatus (Bowdich, 1825). NFS Journal, v. 4, p. 27-31, 2016.

OLIVEIRA, R.C.; DÓREA, J.G.; BERNARDI, J.V.; BASTOS, W.R.; ALMEIDA, R.; MANZATTO, Â.G. Fish consumption by traditional subsistence villagers of the Rio Madeira (Amazon): impact on hair mercury. Annals of human biology, v. 37, n. 5, p. 629-642, 2010.

PAL, J.; SHUKLA, B.; MAURYA, A. K.; VERMA, H. O.; PANDEY, G.; AMITHA. A review on role of fish in human nutrition with special emphasis to essential fatty acid. International Journal of Fisheries and Aquatic Studies, v. 6, n. 2, p. 427-430, 2018.

PEREIRA, O.N.A.; DE CASTRO, E.M.N.V.; BASTOS, M.R.; DIAS, J.A.; DA CONCEIÇÃO RODRIGUES, M.A.; DA FONSECA, L.C. A colonização portuguesa na região de Cabo Frio (Rio de Janeiro, Brasil) e o desenvolvimento da atividade piscatória. Revista Portuguesa de História, v. 48, p. 151-173, 2018.

PRATO, E.; BIANDOLINO, F. Total lipid content and fatty acid composition of commercially important fish species from the Mediterranean, Mar Grande Sea. Food Chemistry, v. 131, n. 4, p. 1233-1239, 2012.

POSTE, A.E.; MUIR, D.C.G.; GUILDFORD, S.J.; HECKY, R.E. Bioaccumulation and biomagnification of mercury in African lakes: The importance of trophic status. Science of The Total Environment, v. 506-507, p. 126-136, 2015.

RANI, P.; KUMAR, P.V.; RAO, K.R.; SHAMEEM, U. Seasonal variation of proximate composition of tuna fishes from Visakhapatnam fishing harbor, East coast of India. International Journal of Fisheries and Aquatic Studies, v. 4, n. 6, p. 308-313, 2016. 
ROMOTOWSKA, P.E.; KARLSDÓTTIR, M.G.;

GUDJÓNSDÓTTIR, M.; KRISTINSSON, H.G.; ARASON, S. Seasonal and geographical variation in chemical composition and lipid stability of Atlantic mackerel (Scomber scombrus) caught in Icelandic waters. Journal of Food Composition and Analysis, v. 49, p. 9-18, 2016.

RULEV, N.; MAKAROVA, A.J.R.K., MOSCOU. Technical and chemical characteristics of the Atlantic herring as industrial raw material (em russo). v. 35, n. 3, p. 51-4, 1959.

SÁNCHEZ-MUROS, M.J.; MOROTE, E.; GIL, C.; RAMOSMIRAS, J.J.; TORRIJOS, M.; RODRÍGUEZ MARTIN, J.A. Mercury contents in relation to biometrics and proximal composition and nutritional levels of fish eaten from the Western Mediterranean Sea (Almería bay). Marine Pollution Bulletin, v. 135, p. 783-789, 2018.

SIDDIQUE, M.; MOJUMDER, P.; ZAMAL, H. Proximate composition of three commercially available marine dry fishes (Harpodon nehereus, Johnius dussumieri and Lepturacanthus savala). American Journal of Food Technology, v. 7, n. 7, p. 429436, 2012.

SILA, A.; BOUGATEF, A. Antioxidant peptides from marine byproducts: Isolation, identification and application in food systems. A review. Journal of Functional Foods, v. 21, p. 10-26, 2016.

SILVA, C.A.D.; TESSIER, E.; KÜTTER, V.T.; WASSERMAN, J.C.; DONARD, O.F.X.; SILVA-FILHO, E.V. Mercury speciation in fish of the Cabo Frio upwelling region, SE-Brazil. Brazilian Journal of Oceanography, v. 59, p. 259-266, 2011.

SILVA, S.F.D.; OLIVEIRA, D.C.; PEREIRA, J.P.G.; CASTRO, S.P.; COSTA, B.N.S.; LIMA, M.D.O. Seasonal variation of mercury in commercial fishes of the Amazon Triple Frontier, Western Amazon Basin. Ecological Indicators, v. 106, p. 105549, 2019.

SUVITHA, S. Proximate, Amino acid and Fatty acid profile of selected two Marine fish from Parangipettai Coast. Asian Journal of Biomedical Pharmaceutical Sciences, v. 5, n. 40, p. 38, 2015.

STANCHEVA, M.; MERDZHANOVA, A.; PETROVA, E.; PETROVA, D. Heavy metals and proximate composition of Black Sea sprat (Sprattus sprattus) and goby (Neogobius melanostomus). Bulgarian Journal of Agricultural Science, v. 19, n. 1, p. 35-41, 2013.
VOLLENWEIDER, J.J.; HEINTZ, R.A.; SCHAUFLER, L.; BRADSHAW, R.J.M.B. Seasonal cycles in whole-body proximate composition and energy content of forage fish vary with water depth. Marine Biology, v. 158, n. 2, p. 413-427, 2011.

WINBERG, G.; DUNCAN, A. Methods for the estimation of production of aquatic animals. United States of America: Academic Press, 1971.

WOLFF, S.; BROWN, G.; CHEN, J.; MEALS, K.; THORNTON, C.; BREWER, S.; CIZDZIEL, J.V.; WILLETT, K.L. Mercury concentrations in fish from three major lakes in north Mississippi: Spatial and temporal differences and human health risk assessment. Journal of Toxicology and Environmental Health: Part A, v. 79, n. 20, p. 894-904, 2016.

WU, Z.X.; HU, X.P.; ZHOU, D.Y.; TAN, Z.F.; LIU, Y.X.; XIE, H.K.; RAKARIYATHAM, K.; SHAHIDI, F. Seasonal Variation of Proximate Composition and Lipid Nutritional Value of Two Species of Scallops (Chlamys farreri and Patinopecten yessoensis). European Journal of Lipid Science and Technology, v. 121, n. 7, p. 1800493, 2019.

WÜRZBERG, L.; PETERS, J.; FLORES, H.; BRANDT, A. Demersal fishes from the Antarctic shelf and deep sea: A diet study based on fatty acid patterns and gut content analyses. Deep Sea Research Part II: Topical Studies in Oceanography, v. 58, n. 19, p. 2036-2042, 2011.

XU, Q.; ZHAO, L.; WANG, Y.; XIE, Q.; YIN, D.; FENG, X.; WANG, $D$. Bioaccumulation characteristics of mercury in fish in the Three Gorges Reservoir, China. Environmental Pollution, v. 243, p. 115126, 2018.

ŽÁČEK, P.; BUKOWSKI, M.; JOHNSON, L.; RAATZ, S. K.; PICKLO, M. Selective enrichment of $n-3$ fatty acids in human plasma lipid motifs following intake of marine fish. The Journal of Nutritional Biochemistry, v. 54, p. 57-65, 2018.

ZAHIR, F.; RIZWI, S.J.; HAQ, S.K.; KHAN, R.H. Low dose mercury toxicity and human health. Environmental Toxicology and Pharmacology, v. 20, n. 2, p. 351-360, 2005.

ZHANG, W.; ZHANG, X.; TIAN, Y.; ZHU, Y.; TONG, Y.; LI, Y.; WANG, X. J. J. O. H. M. Risk assessment of total mercury and methylmercury in aquatic products from offshore farms in China. Journal of Hazardous Materials, v. 354, p. 198-205, 2018. 